\title{
ÉJSZAKAI LÉGZÉSZAVAR EPIZÓDOK ÉS A SZÍVFREKVENCIA VARIABILITÁS KAPCSOLATA
}

\author{
RELATIONSHIP BETWEEN NIGHT-TIME DYSPNEA EPISODES AND HEART RATE \\ VARIABILITY
}

\author{
Szabó Krisztina1 ${ }^{1}$ Balogh László2, Ihász Ferenc ${ }^{1,2}$ \\ 1Pécsi Tudományegyetem, Egészségtudományi Kar, Egészségtudományi Doktori Iskola; ${ }^{2}$ Sümeg \\ Járóbeteg Szakellátó Központ.
}

\begin{abstract}
Összefoglaló
Bevezetés: Vizsgálatunk célja volt összehasonlítani, a szívfrekvencia variabilitás éjszakai és nappali értékeit alvási apnoe szindrómában szenvedők és kontroll csoport között. Célunk volt továbbá vizsgálni, az apnoe súlyosságának hatását a HRV index mutatókra.

Célkitüzés: Célunk volt vizsgálni, hogy az éjszakai légzészavar epizódok befolyásolják -e a HRV indexeket.

Módszer: A vizsgálatban 40 fó adatait elemeztük, akik közül 20 személy alvási apnoes. A kontroll csoportba 20 olyan személy adatai kerültek, akiknek nincs alvási apnoéjuk. A szívfrekvencia variabilitás idő és frekvencia paramétereit vizsgáltuk, melyhez 24 órás Schiller Medilog Holter monitor által rögzített adatok nappali és éjszakai értékeit használtunk. A két csoport átlagának eltérését kétmintás t-próbával vizsgáltuk, ahol a p<0,05.

Eredmények: A vegetatív egyensúlyi arányszámot és az $R$-R intervallumok standard deviációját vizsgálva, egyaránt szignifikáns különbséget kaptunk az apnoes betegek és egészséges csoport között az éjszakai időszakban. Az apnoe súlyosságát vizsgálva az idő és frekvencia mutatók átlagában nem találtunk szignifikáns különbséget a két csoport között, azonban az apnoes csoport értékeinek szúkülése a kontroll csoporthoz képest megfigyelhetó.

Következtetés: Az apnoes betegek és a kontroll csoport vegetatív egyensúlyi arányszámának és idő paramétereinek éjszakai különbségei, illetve a kórkép súlyosságának változásával regisztrálható HRV mutató eltérések felhívják a figyelmet, a HOLTER monitorral mért HRV mutatók jelentôségére az éjszakai légzészavar epizódok szürésének lehetőségére.
\end{abstract}

Kulcsszavak: Szívfrekvencia variabilitás, légzészavar epizód, cirkadián ritmus 
Vol 3, No 1 (2020): Stadium - Hungarian Journal of Sport Sciences

https://doi.org/10.36439/SHJS/2020/1/5422

\begin{abstract}
Purpose: We wanted to assess the values of expected night-time and day-time variability of the heart rate, in the presence of dyspnea episodes during night-time, recorded by a Holter monitor.

Objective: Our aim was to investigate whether nocturnal breathing disorders affect the HRV indexes.

Methods: 40 patients participated in our survey. 20 of them experienced episodes of night-time breathing difficulty, and the control group consisted of 20 participants in whose case there were no episodes of night-time breathing difficulty. We were examining the domains of time and frequency of heart rate variability, using day-time and night-time values recorded by a 24-hour Schiller Medilog Holter monitor. We evaluated the distribution of the parameters with a continuous codomain, their typical distribution and expected values on histograms, and summarized them in a table. For the examination of the difference in averages the Two-Sample $T$ - Test was used, where $p<0.05$.

Results: The vegetative equilibrium ratio and the standard deviation of the $R$ - $R$ intervals showed a significant difference between the apnea patients and the healthy group at night. Examining the severity of apnea, we didn't find significant difference between the two groups in the mean of the time and frequency indices, however, a decrease in the values of the apnea group was observed compared to the control group.

Conclusion: Night differences in the vegetative equilibrium rate and time parameters of the apnea patients and the control group, as well as differences in the HRV index recorded by the change in the severity of the disease, draw attention to the importance of the HRV indicators with HOLTER monitors.
\end{abstract}

Keywords: Heart rate variability, episode of breathing difficulty, circadian rhythm 


\section{Rövidítések}

HRV= Szívfrekvencia variabilitás (Heart Rate Variabilty); OSAS= Obstruktív alvási apnoe szindróma (Obstructive sleep apnea syndrome); $\mathrm{AHI}=$ apnea-hypnea index; SDNN =R-R intervallumok standard deviációja (standard deviation of normal R-R intervals); $\mathrm{LF}=$ alacsony frekvenciatartomány (low-frequency power); $\mathrm{HF}=$ magas frekvenciatartomány (high-frequency power); LF/HF= vegetatív egyensúlyi arány (low-frequency power/ high-frequency power); ANS= autonom idegrendszer (autonomic nervous system) ;NREM= szemmozgás nélküli alvásciklus (non -rapideye- movement)

\section{Elméleti háttér}

A kardiovaszkuláris egészség fontos tényezője a nyugalmi kardiovagalis aktivitás. Egészséges szív esetében a nyugalmi szívfrekvencia 72/perc, melyet a paraszimpatikus hatások dominanciája eredményez. A szívfrekvencia variabilitás (HRV) mértéke információt szolgáltat a szív válaszkészségéről és a perifériás idegek működéséről egyaránt. Az elmúlt időszakban keletkezett tanulmányokban szignifikáns összefüggést mutattak ki a kardiovaszkuláris mortalitás gyakorisága, a hirtelen szívhalál és az autonóm idegrendszer működése között [SHWARTZ PRIORI,1990].

A vegetatív idegrendszer döntő szerepet játszik az egyes aritmiák, különösen a pitvarfibrilláció kialakulásában, annak fennmaradásában és megszűnésében egyaránt. A pitvarfibrillació kialakulásának esélye jelentősen nő az OSAS megléte mellett, emelve ezzel a stroke kialakulásának esélyét is [MATASSINI et al., 2014]. Gazdag paraszimpatikus beidegzést kap a sinus csomó és az atrioventrikularis csomó. Ezeket a területeket, illetve a kamrák munkaizomzatát a szimpatikus idegrendszer szintén beidegzi. Míg a paraszimpatikus hatások a szívfrekvenciát és az ingerület vezetési sebességet mérséklik, a szimpatikus hatás ezeket fokozza. A szív aritmiakészsége nő a vagushatás csökkenésével, különösen a kamrai tachyaritmiák valószínűségét növeli. Klinikailag egészséges populációban az emelkedett szívfrekvencia a hirtelen szívhalál előfordulási gyakoriságát jelzi. [KANNEL et al., 1987; WANNAMETHEE et al., 1995]. A szívfrekvencia és a vérnyomás éjszakára jellemző fiziológiás csökkenésének elmaradásáért, a paraszimpatikus tónus csökkenése illetve a szimpatikus és paraszimpatikus egyensúly felborulása a felelős. [CHEN et al.,1998]. A hirtelen szívhalált előidéző ritmuszavarok kifejlődésének hátterében leggyakrabban elektrolit eltérések, ischaemia és az autonóm idegrendszer aktivitásának ingadozása áll. [ACHARYA et al., 2006]. Az NN- intervallumok folyamatos változásának befolyásolása az autonóm idegrendszer feladata, a sinus csomó receptoraira direkt módon befolyásoló hatása által. Azok a kórállapotok, melyek befolyással bírnak a vegetatív idegrendszer aktivitására, módosíthatják az NN- intervallumok variabilitását. A szívfrekvencia variabilitás analízis mérőszámai vonatkozhatnak az időbeni 
különbségek leírására, illetve leírható az NN -távolságkülönbségek teljesítményeloszlása a frekvencia függvényében. A „time domainek” közül leggyakrabban használt mérőszám, az egyes ciklusok hosszúságának átlaga (mRR) illetve azok szórása (mSDRR), továbbá az egymás utáni ciklusok hosszúságának különbségei (NN) és ezek standard deviációja (SDNN). A Fast Fourier transzformáció segítségével, a szívfrekvencia periodicitását frekvencia komponensekre bonthatjuk. A szívfrekvencia növekedése, a szimpatikus idegek ingerlését követően csak bizonyos látenciával jelenik meg. Azokat a szívfrekvencia változásokat, melyek 7 másodpercnél rövidebb periódusidejúek a szimpatikus idegrendszer nem képes közvetíteni. Ezek a 0,15 Hznél nagyobb, azaz magas (high-frequency power, HF: 0,15-0,40Hz) frekvenciájú tartományok. Az alacsony frekvenciatartomány (low-frequency power, LF) a 0,04$0,15 \mathrm{~Hz}$ közé eső frekvenciatartomány. Az alacsony és magas frekvenciák aránya (LF/HF) a vegetatív egyensúlyra utal, információt szolgáltat a szimpato-vagális egyensúlyról.

A spektrális HRV indexek élettani értelmezése még hiányos annak ellenére, hogy újabb HRV mutatókról is olvashatunk, melyek nem csupán a kardiovaszkularis, de más patológiás állapotok esetén is olyan információkat nyújtanak, melyek miatt a klasszikus rizikófaktorok közé történő sorolásukat javasolják [BUCHHEIT et al., 2008]. A cirkadián ritmus szignifikáns összefüggést mutat az immunrendszeri megbetegedésekkel, rheumatoid arthritissel és a kardiometabolikus rendellenességekkel egyaránt. Fentiek mellett a cirkadián diszfunkció véralvadásban és a kardiovaszkularis események előfordulásában betöltött szerepére is fény derült [HALMOS - SUBA, 2012]. 17 éves prospektív vizsgálatukban Nilson és mtsai összefüggést találtak a kardiovaszkularis mortalitás és az alvászavar között [NILSON et al., 2001]. Az alvás alatt bekövetkező légzészavar epizódokkal járó megbetegedés, az alvási apnoe szindróma, szoros összefüggést mutat a kardiovascularis megbetegedésekkel, diabetesszel, metabolikus szindrómával és egyes tüdőbetegségekkel egyaránt [TORZSA, 2009]. A szív, tüdő és agykárosodások esélyét sokszorosára növeli, mely miatt a stroke és a myocardialis infarctus független rizikófaktorának tekintjük. A szívfrekvencia és a vérnyomás értékek $10-15 \%$ al csökkennek a NREM alvásban a nappali értékekhez képest. Az alvásciklusok leszálló ágán a vérnyomás és szívfrekvencia is csökken, míg a felszálló ágán növekszik. A légzészavar epizódokat kezdetben vagotonia jellemzi, majd az ébredéssel szimpatikotonia jelentkezik, amely hirtelen fokozódik. Az alvásciklus fiziológiás töredezettsége vezet a noradrenalin fokozott kiválasztásában bizonyított szimpatikus tónus fokozódás kialakulásához, mely a renin-angiotensin rendszer hosszú távú torzulását eredményezheti [VÁRDI VISI, 1996].

\section{Módszer}


A vizsgálatban ( $n=40$ személy,) 20 férfi $(60,7 \pm 9,3$ év) és 20 nő ( $67 \pm 8,6$ év) adatait elemeztük. A vizsgálatba bevont személyek nem szenvednek kardiovaszkularis megbetegedésben (angina pectoris, st.p.miocardialis infarctus, pitvarfibrillatio, vagy egyéb arrithmia). Az EKG amplitúdó mikrovolt nagyságú változásainak rögzítése nagyfelbontású felvevő készülékkel lehetséges. A szívfrekvencia variabilitásának mintázatának elemzéséhez Schiller Medilog Holter készülék, $8000 \mathrm{~Hz}$ mintavételi frekvencián rögzítette az adatokat, melyekből 1000 Hz frekvencián nagy felbontású HRV analízis idő és frekvencia paramétereit elemeztük. A rögzített adatok közül, az Európai Kardiológus és az Észak-Amerikai Ritmus -és Elektroélettani Társaság ajánlása alapján [EUROPEAN SOCIETY OF CARDIOLOGY AND THE NORTH AMERICAN SOCIETY OF PACING AND ELECTROPHYSIOLOGY, 1996 ], az idő paraméterek közül az SDNN-t, azaz a R-R intervallumok standard deviációját az összes normális ciklus figyelembevételével, a frekvencia paraméterek közül pedig az 0,04-0,15 Hz-ig terjedő alacsony, valamint a magas 0,15-0,4 Hz közé eső frekvenciákat, illetve ezek arányát elemeztük. A HRV diurnális mintázatának megfigyelése céljából az értékeket nappali (7-22 óráig) és éjszakai (22-7 óráig) időszakokra bontva vizsgáltuk. A két csoport átlagainak eltérését kétmintás t-próbával az RR intervallumok összesített szórás átlagait, illetve a vegetatív egyensúlyi arányszámok éjszakai és nappali jellemzőit az egészségesek és a betegek vonatkozásában F-próbával vizsgáltuk.

\section{Eredmények}

Az alvási apnoés szindrómás betegek, illetve az egészségesek csoportjaiban a HRV idő paramétere szignifikáns különbséget mutatott az éjszakai alvás során. (1.ábra). SDNN éj $[(1)=44,32, C I=37.2-(2)=56.77 ; C I=47.8 ; F(1 ; 38)=5,1543] ; p=0,0289$, SDNN nappal: $[(1)=48.92, \mathrm{CI}=37.68-(2)=53.11, \mathrm{CI}=45.19 ; \mathrm{F}(1 ; 38)=0,4057] ; \mathrm{p}=0,5280$

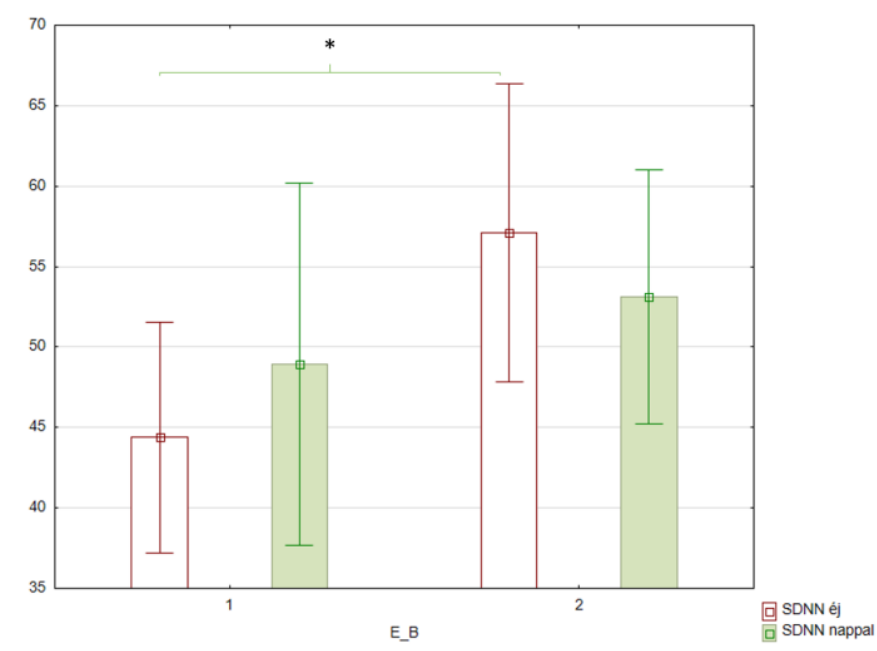

1. ábra: A HRV idő paraméter értékei egészségesekben és betegekben nappal és éjjel 
Vol 3, No 1 (2020): Stadium - Hungarian Journal of Sport Sciences

https://doi.org/10.36439/SHJS/2020/1/5422

Az ábra az egészséges és apnoes betegek SDNN paraméterét ábrázolja a nappali és éjszakai időszakban.

Rövidítések: SDNN= HRV idő paraméter

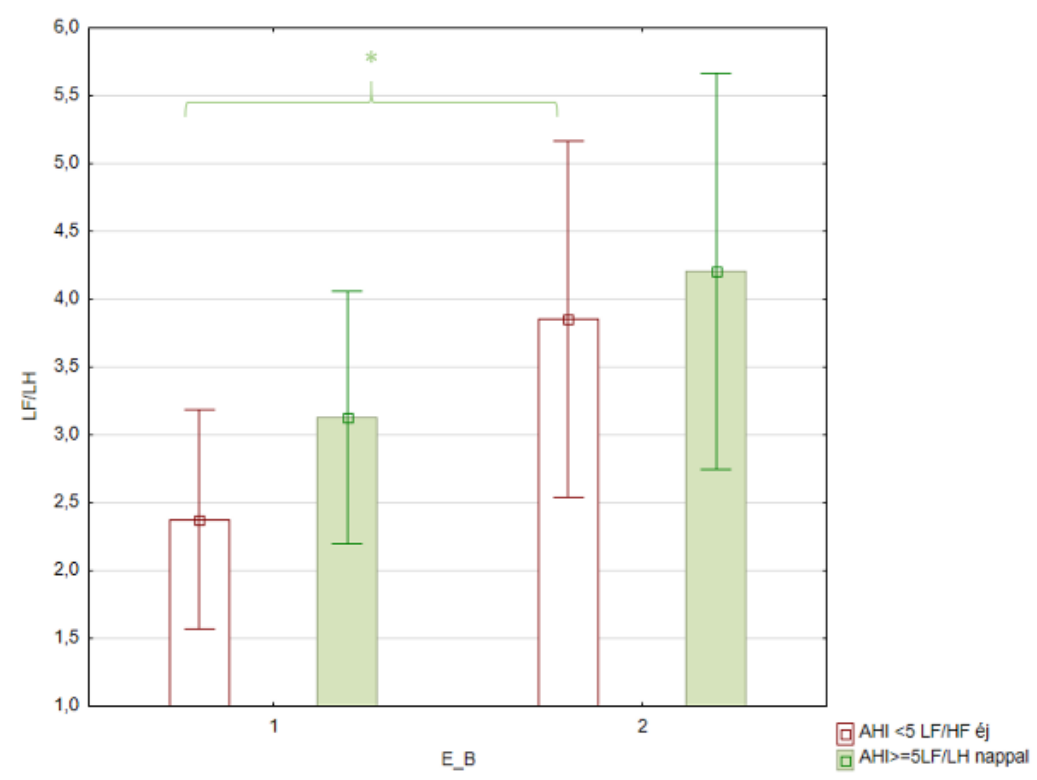

2. ábra Vegetatív egyensúlyi arányszám nappal és éjjel

Az ábra az apnoes betegek és egészségesek vegetatív egyensúlyi arányszámát mutatja, nappali és éjszakai bontásban.

Rövidítések: $\mathrm{AHI}=$ apnoe-hypnoe index, $\mathrm{LF} / \mathrm{HF}=$ vegetatív egyensúlyi arányszám

A vegetatív egyensúlyi arányszámok összehasonlításánál, szignifikáns különbség mutatkozott az éjszakai légzészavarral küzdők és az egészségesek eredményei között az éjszakai időszakban. (2.ábra). LF/HF éj $[(1)=2,37$; $(\mathrm{CI}=1,56)-(2)=3,83 ;(\mathrm{CI}=5,15)$; $\mathrm{F}(1 ; 38)=4,0228] \mathrm{p}=0,0500$. A nappali tevékenységben nem találtunk valódi különbséget AHI <5 LF/HF nappal [(1)=3,13; (CI=2,19) - (2) = 4,21; (CI=2,74) $\mathrm{F}(1 ; 38)=1,7099 ; \mathrm{p}=0,1989$.

Az OSAS betegek adatait, a kórkép klinikai súlyossági fokozatainak megfelelően bontottuk két csoportra. Az alvás óránként 5-15 AHI melletti enyhe, és az alvás óránként 15-30 AHI melletti közepes OSAS csoportba sorolva. A HRV idő és frekvencia mutatóinak átlagát éjszakai és nappali bontásban összehasonlítva a két csoport között szignifikáns különbséget nem kaptunk, azonban az óránkénti légzészavar epizódok számának emelkedésével a HRV idő paraméterének szűkülése figyelhető meg mind éjjel mind nappal. SDNN éjszaka: [(1)=60,07, CI=48,62 - (2) =43,29; CI=28,6); F(1;17) $=3,0031] ; \mathrm{p}=0,1012$; SDNN nappal: $[(1)=54,08, \mathrm{CI}=43,38-(2)=46,91, \mathrm{CI}=33,7$; $\mathrm{F}(1 ; 17)=0,7172] ; \mathrm{p}=0,4088$. (3. ábra) 


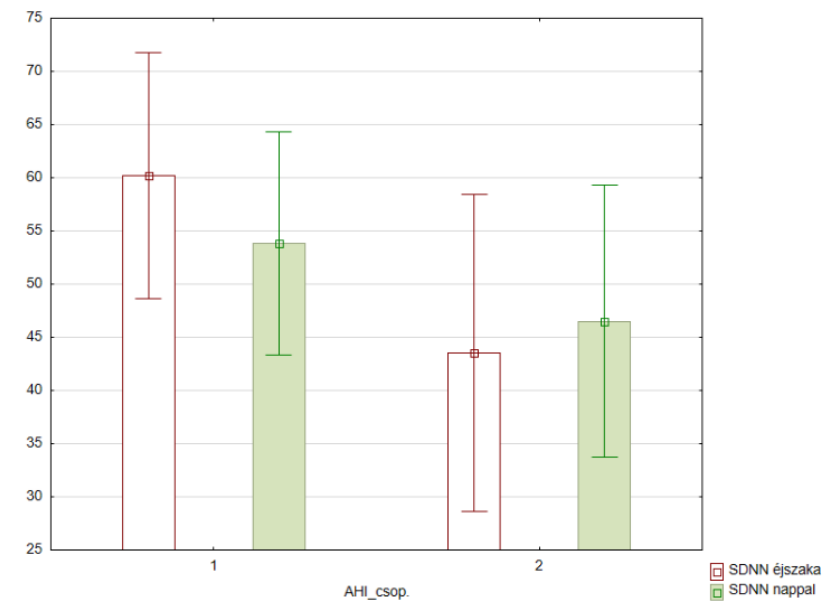

3. ábra: A HRV idő paramétere nappal és éjjel a kórkép súlyossága szerint

Az ábrán az alvási apnoes betegek idő paramétereit ábrázoltuk nappali és éjszakai bontásban, illetve az apnoe súlyossága szerinti csoportosításban.

Rövidítések: $\mathrm{AHI}=$ apnoe-hypnoe index, $\mathrm{SDNN}=\mathrm{HRV}$ idő paraméter

A közepes OSAS csoportba tartozók nappali vegetatív egyensúlyi arányszáma jelentősen növekedett az enyhe OSAS csoportba tartozó személyek értékeihez képest. LF/HF nappal $[(1)=3,97, \mathrm{CI}=1,93-(2)=3,71, \mathrm{CI}=1.65 ; \mathrm{F}(1 ; 17)=1,5526] ; \mathrm{p}=0,2297$. LF/HF éjszaka $[(1)=3.82, C I=1.94-(2)=5.79, C I=9.12 ; F(1 ; 17)=0,0273] ; p=0,8706$. (4. ábra)

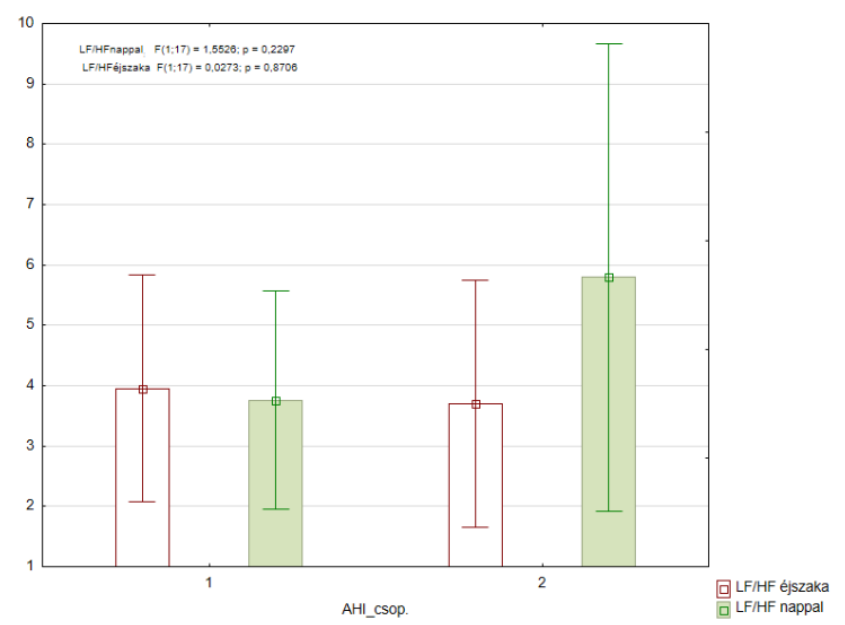

4. ábra. Vegetatív egyensúlyi arányszám nappal és éjjel a kórkép súlyossága szerint

Az ábrán az alvási apnoes betegek frekvencia paramétereit ábrázoltuk nappali és éjszakai bontásban, illetve az apnoe súlyossága szerinti csoportosításban. 
Rövidítések: $\mathrm{AHI}=$ apnoe-hypnoe index, $\mathrm{LF} / \mathrm{HF}=$ Vegetatív egyensúlyi arányszám

\section{Megbeszélés}

Vizsgálatunkban összehasonlítottuk a szívfrekvencia variabilitás éjszakai és nappali értékeit alvási apnoe szindrómában szenvedők és kontroll csoport között. A kapott eredmények mind az éjszakai vegetatív egyensúlyi arányszám mind az éjszakai R-R intervallumok standard deviációjának különbségére hívják fel a figyelmet. Hasonló eredményre jutottak korábbi vizsgálat eredményei is, melyben OSAS és UARS páciensek HRV értékeit vizsgálták. A légzészavar epizódok alatt HRV változásokat találtak a NREM szakaszok alatt. A frekvencia paraméterek közül, az LF/HF érték mutatott szignifikáns növekedést. Az ANS kiemelkedően fontos szerepet játszik az alvás során is. Az alvás alatt jelentkező légzési rendellenességek megzavarhatják a szimpatikus és paraszimpatikus interakciók rendkívül komplex egyensúlyát. [GUILLEMINAULT et al., 2005]. Szintén HRV komponensek szignifikáns különbségeit vizsgálták olyan OSAS pácienseknél, akiknél nem volt ismert kardiovaszkuláris megbetegedés. Megnövekedett szimpatikus aktivitást, beszűkült R-R variabilitást találtak. [NARKIEWICZ et al., 1998]. Korábbi tanulmányban vizsgálták az alvásidő és HRV összefüggéseit. Eredményeik szerint, az OSAS betegek esetében fennálló ANSrendellenességek a hypoxiás epizódokhoz köthetőek, nem pedig a megrövidült alvásidőhöz. [CARNETHON et al., 2012]. Fentiek felhívják a figyelmet, az alvás alatt bekövetkező légzészavarok kardiovaszkuláris rendszerre gyakorolt hatására. Egy Brazil vizsgálatban, 25 személyen HRV idő és frekvencia paraméterek változásait vizsgálták olyan betegek esetében, akiknél áramlási zavarok jelentkeztek, azonban az AHI $<5$, tehát nem tartoznak az OSAS betegek közé. Eredményeik szerint azok a légzészavarok melyek nem merítik ki az OSAS diagnosztikai kritériumokat is szignifikáns különbséget mutattak az abnormális autonóm szabályozással. Légzészavar epizódok jelentkezhetnek mikró ébredés (RERA) nélkül is, melyek önmagukban is összefüggésben állnak az abnormális autonóm szabályozással. [

PALOMBINI et al., 2006]. A HRV paraméterek analízise megbízható módszer az autonóm kardiális moduláció változásainak felmérésére, beteg és egészséges személyen egyaránt. Fontos információkat szolgáltat a klinikai és prognosztikai relevanciáról egyaránt. [TOBALDINI et al., 2013]. Súlyos OSA-betegek esetében a HRV 
értékelést jelentősen befolyásolhatják, a folyamatos apnoés epizódok, melyek nem neurális változásokként HRV-t befolyásoló tényezők lehetnek. [WANG CHARKOUDAIN, 2007]. Egészséges gyermekeknél vizsgálták az LF, HF és a szimpatovagális egyensúlyi arányszámokat illetve a légzés teljesítményspektrumát, melyet Fast Fourier transzformációs módszerrel elemeztek. Eredményük alapján elmondható, hogy a HRV spektrum analízise, könnyen alkalmazható non invazív módszer az autonóm aktivitás körvonalazására. [BAHARAY et al., 1995]. Holter monitor által rögzített adatokból a HRV idő és frekvencia paramétereinek értékélésével invazív és költséghatékony módon fedezhetők fel a légzészavar epizódok, melyek felhívják a figyelmet az alvással összefüggő légzési rendellenességekre. [PALOMBINI et al., 2006]. A HRV idő és frekvencia paramétereinek eltérései felhívják a figyelmet, a HOLTER monitorral mért HRV mutatók jelentőségére az éjszakai légzészavar epizódok szűrési lehetőségében. 


\section{Irodalomjegyzék}

Acharya, U. R., Joseph, K. P., Kannathal, N., et al (2006). Heart rate variability: a review. Med. Bio. Eng. Comput., 44, (12), 1031-1051.

Baharav A, Kotagal S, Gibbons V, Rubin BK, Pratt G, Karin J, \& Akselrod S. (1995). Fluctuations in autonomic nervous activity during sleep displayed by power spectrum analysis of heart rate variability. Neurology, 45, (6), 1183-7.

Buchheit, M; Millet, G. P., Parisy, A. et al. (2008). Supramaximal training and post exercise parasympathetic reactivation in adolescents. Med. Sci. Sports. Exerc., 40, 362371.

Carnethon M., Knuston K. L., Ng J., de Chavez P. J., Kim K. Y., Liu K., Zee P., \& Goldberger J. J. (2012). Association of Sleep Characteristics with Heart Rate Variability: Chicago Area Sleep Study. Circulation, 125, AP203.

Chen J. W., Jen S. I., et al. (1998). Differential glucose tolerance in dipper and nondipper essential hypertension: the implications of circadian blood pressure regulation on glucose tolerance in hypertension. Diabetes Care, 21,1743-1748.

Guilleminault C., Poyares D., Rosa A., \& Huang Y. S. (2005). Heart rate variability, sympathetic and vagal balance and EEG arousal in upper airway resistance and mild obstructive sleep apnea syndromes. Sleep Medicine, 6, 451-457.

Halmos T., Suba I. (2012). Physiological and patophysiological role of the circadian clock system. [ A cirkadiánclock-rendszer élettani és patológiai szerepe] Orvosi Hetilap, 153, ( 35) , 1300-1379. [Hungarian]

Heart rate variability: standards of measurement, physiological interpretation and clinical use. Task Force of the European Society of Cardiology and the North American Society of Pacing and Electrophysiology. (1996). Circulation, 93, 1043-65. 
Kannel, W. B., Kannel, C., Paffenbarger, R. S., \& Cupples L. A. (1987). Heartrate and cardiovascular mortality: the Framingham Study. Am Heart J., 113, (6), 1489-94.

Matassini M. V., Brambatti M., Guerra F., Scappini L., \& Capucci A. (2014). Sleep Disordered Breathing and Atrial Fibrillation: Review of the Evidence. Cardiol Rev.

Narkiewicz K., Nicola M., Chiara C., et al. (1998). Altered cardiovascular variability in obstructive sleep apnea. Circulation, 98:1071-7.

Nilson P., Nilson J. A., at al (2001). Sleep Disturbances in association with elevated pulse rate for the predictor of mortality-consequences of mental strain? J Intern Med, 250, 521-29.

Palombini L., Kauti A., Poyares D., Guilleminault C., \& Tufik S. (2006). Heart rate variability in continuous flow limitation during sleep. Sleep Medicine, 7, 257.

Schwartz, P. J., Priori, S. G. (1990). Sympathetic nervous system and cardiac arrythmias. In: Zipes, D. P., Jalife, J. (eds.): Cardiac electrophysiology: From cell to bedside. WB Saunders Co, Philadelphia,

Tobaldini E, Nobili L, Strada S, Kasali R.K, Braghiroli A., \& Montano N. (2013). Heart rate variability in normal and pathological sleep. Front Physiol, 4, 294.

Torzsa P. (2009). Az obstruktív alvási apnoe és a horkolás epidemiológiája és klinikai jelentősége a családorvosi gyakorlatban. Budapest, Semmelweis Egyetem, Mentális Egészségtudományok Doktori Iskola.

Várdi Visy K. (1996). Breathing disorders during sleep. [ Légzészavarok alvás közben] Budapest, Medicina Kiadó; 19-21 [Hungarian]

Wang B.G, Charkoudain N. (2007). Association of cardiac autonomic function measures with severity of sleep-disordered breathing in a community-based sample. J. Sleep Res, 17, 251-262. 
Vol 3, No 1 (2020): Stadium - Hungarian Journal of Sport Sciences

https://doi.org/10.36439/SHJS/2020/1/5422

Wannamethee G, Shaper AG, Macfarlane PW, \& Walker M. (1995). Risk factors for sudden cardiac death in middle-aged British men. Circulation., 91, (6), 1749-56. 